UDC 1(091)

EBO SOCRATES,

Institute of Foundation Studies, Federal University (Otuoke, Bayelsa State, Nigeria)

e-mail: eboss@fuotuoke.edu.ng.ebosocrates@gmail.com,ORCID http://orcid.org/0000-0003-4062-8487

\title{
DEATH IN IGBO AFRICAN ONTOLOGY
}

Death is man's ultimate challenge. It is his ultimate puzzle. It is at the center of man's quest for the meaning of his existence. Different cultures at various eras have approached death from their gamut of meanings. The Igbo African society like other cultures in the world have confronted death in their attempt to philosophically give meaning to their experiences. Ndigbo like the majority of the human race, have refused to accept the finality of death. No. Man shouldn't just disappear. Among the Ndigbo, death is a continuum. The dead continue to live in the memory and activities of the community. Their status in the land of the dead, which by the way is not far removed from the community depends on how well they had lived and how well their progeny had discharged their duties towards them, especially by according them a befitting burial. In the Igbo ontology, the society is the center of existence. Even in the world of the dead, the dead exist for the society. They must continue to bid well for the community by granting it favorable auspices from the gods. Even when the dead don't make it into the comity of the ancestors, they don't just disappear. They hang around the community, causing great nuisances to their immediate family and the community at large. When the Igbo dies, he does not desire to be united to any god in any heaven nor to be punished by any demon in a hellfire. His being is essentially defined as "being with the community". This work $x$-rays $t$ the Igbo unique way of approaching death, relying on library research, oral traditions and interviews, direct observations of the community's customs in practice and analyses of lived experiences in the community. It aims at bringing out distinctly in philosophical formation, the uniquely Igbo conceptualization of death as it relates to the meaning of life.

Keywords: Death; quest for the meaning of his existence; Igbo African society; Igbo conceptualization of death.

Introduction

Ndigbo like the rest of humanity have responded to the anxiety posed by the finality of death and the fate of the human personality after death (Myers, 1903). All cultures have wondered on the fate of man after he loses consciousness and personal identity in death and subsequent decay. Could this be the end of such a gloriously wonderful being as man - mmadu? Man in Igbo is mmadu. It literally translates to "behold beauty". Like cultures all over the world, Ndigbo have come up with answers and coping mechanisms to confront death.

Death in Igbo African ontology is a continuum (Anuolam, 1993). The dead continue to exist in the consciousness of the living. Existentially, the community does not consider them gone and lost (Ikwueme \& Onwuegbuna, 2018). The community rather assigns them a prestigious position in the corpus of meaning in the society. Of course, only if they had met certain benchmarks set by the community. Since death is at the very core of meaning of existence among men, Ndigbo deciphered the meaning of death from the concept of self in lgbo ontology. Subsequently the meaning of death cannot be grasped without understanding the concept of self in Igbo ontology. Since death is the ultimate experience of the self, it becomes a necessity for its meaning to be derived from the interpretation of the self.

Ndigbo are not the only culture to tie the meaning of life to the meaning of death. It appears to be a universal practice. Man is basically a survivor. Life is his most prized possession. In all his endeavors, man looks out for his life. Even when he commits suicide, he does so seemingly to save his life from a perceived unbearable situation. Death is therefore given meaning in relation to life. Philosophers from the earliest times recognized the pivotal importance of death in relation to life. The doctrines of immortality of the soul and metempsychosis are products of this unique relation of the meaning of death to the meaning of life.

The meaning of death occupies no less important position in the formulation of the ethical dictates of the society. Ethics is a teleological chart way. Beyond the peace and harmony of the society, ethical propositions require certain behaviors that will guarantee man's wellbeing even in death (Trothen \& Mercer, 2017). This practice is not peculiar to the Igbo African societies but fairly ubiquitous across the globe. The end of live drives ethics. The end of life cannot be discussed without factoring in the physical end of life which is death.

Methods and Description of the object of study

Who are the Igbos (Ndigbo)? Ndigbo are found in the tropical rainforests of southeastern Nigeria. They congregate majorly at the central region of southeastern Nigeria. However, Ndigbo are found in the southernmost part of Nigeria in Rivers State and Cross River State. They are also found west of the Niger in Delta State. To the north, Igbo communities appear in Benue State and Kogi State, 
all in Nigeria. Beyond Nigeria, Ndigbo are found in Cameroon, Equatorial Guinea, Jamaica and Barbados (Forest, 1994; Mwakikagile, 2006).

Although there are recent unsubstantiated tales linking Igbos to Hebrews, Ndigbo are clearly an autochthonous people (Onochie, 2015). There is no evidence of migration from anywhere in Igbo oral tradition. The Igbo tradition of origin points to Eri as the progenitor of the Igbo race. However, the tradition holds that Eri descended from the sky. This is another way of saying that Eri had no immigration history. The Hebrew account of Igbo origin, which is relatively of recent origin was recently debunked with DNA tests conducted by Israel (Ameh, 2017). Ndigbo, on the contrary have DNA similarities with people of the Niger-Congo area (Veeranah et al, 2010).

Although there are many dialects of the lgbo language, the central Igbo is understood by all Igbo speaking communities. The variations in the language clearly indicate that Ndigbo were not of a single origin. There must have been immigrations and contacts with other peoples which clearly shaped the Igbo language. However, scholars are of the view that the Igbo culture is dominant, hence it continued to be the defining culture even in lgbo communities where there are clear historical evidences of mixture with non-lgbo people. This is largely the case among Western Igbos. Despite the Edoid influences, the culture is distinctly lgbo (Kalu, 2017).

Ndigbo are a fiercely republican people. They had a traditional religious system which was neither doctrinaire in form, political nor with any formal leadership. Although the priestly people of Nri were revered across Igboland, they had no formal control over the Igbo religion. They were especially sought after to perform certain earth cleansing sacrifices. It appears that even the gods were affected by the republican nature of Ndigbo. Ndigbo traditionally do not recognize any supreme god. The concept of "Chukwu", the Supreme Being is a missionary creation. Ndigbo are a traditionally polytheistic people. A very important factor in their religious attitude is that they did not live for the gods. The gods lived for them. Their relationship with the gods was basically a materialistic functionalism. Hence, when a god failed a community, the community simply did away with it (Achebe, 1958).

Like most West African peoples, Ndigbo experienced the transatlantic slave trade. It was a traumatic experience for the slaves as Igbo concept of a slave differed radically from the Western concept of a slave. Among Ndigbo, a slave was not required to do more work than other people in the community. A slave could own a slave of his own, and people were rarely slaves for life (Olaudah, 1837). What obtained in the American plantations was brutal servitude. Consequently, there was a very high rate of suicides among Igbo slaves as they often chose suicide as a way to escape slavery (Loveboy, 2003; Isichei, 2002; Rucker, 2006).

The experience of colonialism like happened among many African peoples led to loss of identity of the lgbo as a distinct nation. Ndigbo became subsumed in Nigeria. The colonial experience led to abrupt disruption in the lgbo traditional way of life. The introduction of Christianity and the warrant chief system were among the major cultural upheavals suffered by Ndigbo.

The Human Experience of Death. Death is the biological cessation of life. The point at which a human being ought to be declared dead is highly controverted. However, the preponderance of scientists hold that a human person ought to be declared dead when he is certified brain dead.
But then, there are technical limitations that challenge this assumption. Since, a person is declared dead when electric activities cease in the neocortex, Miller (2009), challenges using this as the basis for certifying a person dead. $\mathrm{He}$ observed that even when a person is declared brain dead, with the help of life supporting machines, such a person will still be able to excrete, heal wounds and even gestate (in the case of brain dead pregnant females).

Regardless of when death occurs, death decisively results biologically, to loss of consciousness and personal identity. At death, the human person decays and ultimately decomposes into simpler matter. While death among other animals is accepted as the final event in their lives, humans tend to reject death as the final loss of personality and consciousness. In his religions and philosophies, man holds that somehow, consciousness and personal identity do survive death. There ought to be a bodiless realm of being where man will maintain his consciousness and personality in after death.

This is the problem that has led to the investigation of the meaning of death in the Igbo African ontology. Cultures all over the world have accounts of what happens to personal identity after death. The generality of cultures and religions believe that man survives death. The manner in which this survival of death is believed would take place differ from culture to culture. Ndigbo have elaborate ontology of the status of man at death. That is the focus of this work.

This work $x$-rays $t$ the Igbo unique way of approaching death, relying on library research, oral traditions and interviews, direct observations of the community's customs in practice and analyses of lived experiences in the community. It aims at bringing out distinctly in philosophical formation, the uniquely Igbo conceptualization of death as it relates to the meaning of life.

\section{Results and Discussion}

The Meaning of Death in Igbo Ontology. Death in Igbo ontology is inexorably tied to the lgbo concept of being. In the Igbo African society, the individual can only be defined only in relation Meothers (Ogbonna, 2009). One does not exist for himself. He exists for the community. The Igbo community is immortal. Derivatively, the lgbo is immortal as long as he is exists with the community. Since, the lgbo community is immortal, and the self exists only in relation to the community, in Igbo ontology death is necessarily a continuum.

The Igbo conceive their community in two essential components. The living and the ancestors. They are not viewed as dwelling in different communities but in two segments of the one and same community. The ancestors though dead are considered to be alive in the community in the spirit form. Hence the Ndigbo speak of the living dead (Ikechukwu, 2017; Egudu, 1992). Ndigbo speak of spirits but do not speak of a spiritual world. There is no dualism in Igbo cosmology. The Igbo worldview is thoroughly materialistic, and is centered on man. The idea of a spiritual world where a god or a demon is in charge is alien to Ndigbo. Ndigbo conceive of the spirits ndi ichie as the departed, not as non-human entities. Ndigbo regard other non-human principles that act on the cosmos as forces, not spirits. For Ndigbo, the gods are forces, therefore, dwell on earth. The ideas of heaven and hell are foreign to Ndigbo. Ndigbo view any location outside the community, either among the living or in the comity of the ancestors as isolation. That was why the missionaries did not gain much converts among the elderly. The idea of 
a heaven away from the community, away from the comity of ancestors was to them, as much evil as the hellfire which the missionaries preached to them to avoid at all costs.

In a nutshell, the Igbo worldview is materialistic and monistic. Ndigbo believe that man has a spiritual part which survives biological death. However, the surviving personal identity does not migrate to a different world, it remains in the community which is physical and spiritual in character. The Igbo bury their dead in their homesteads because the dead are not considered lost to the family. They are considered to be revered members of the family who intercede for the family for favorable auspices from the gods, and to whom sacrifices must be made from time to time. They are cognitively functional in the community for the living must refer to the precedents set by them as guides to ethical and political conducts in the community. Community identity is central to understanding the lgbo concept of death. The dead yearn to be part of the community, thus even in death they are still tied to the community.

Requirements for Ancestorship. It is not every lgbo person that dies that becomes an ancestor. To qualify to become an ancestor in lgbo ontology, one must satisfy these conditions:

a. Must have attained ripe old age

b. Must have led an ethical life

c. Must not have died by accident

d. Must not have died from certain diseases which the community consider ominous

e. Must not die unwed

f. Must have been accorded a befitting burial.

Among the lgbos, those who died before ripe old age are not considered to have made it into the comity of the ancestors. They simply disappear from existence. They are neither punished nor rewarded. Neither are they required to transmigrate in any form. Death of a youth is a sad event in the community. No father in the traditional Igbo society wishes to bury his son or daughter. In such situations, they are not required to see the corpse.

Not all who die at ripe old age are qualified to enter the comity of the ancestors. The dead must have lived faithfully to the ethical dictates of the community. The ancestors are akin to saints in Christendom. They are role models to be imitated by their family members and the community at large. Those who had lived unethically become wandering spirits akalogheri who are neither welcome among the living nor among the ancestors. They are said to dwell in the wilderness, away from the rest of the community. Their spirits are said to be restless because they are not committed to the comity of the ancestors.

Death by accident is frowned upon by Ndigbo. It is viewed as bad omen requiring sacrifices to appease the gods. Those who die thus are considered to be unfulfilled. They are viewed as unlucky or to have had an unfavorable personal god chi. They do not qualify to enter the comity of ancestors neither do they become akalogheri. They just disappear. Sometimes rituals are carried out to appease their grieving spirits so that they do not become a nuisance to the community.

Among the Igbos, certain diseases such as leprosy and swollen stomach otoro are viewed as bad omens from the gods. People who die from such diseases are deemed unworthy of admittance into the comity of ancestors even when they had led ethical lives. The community however does not designate their spirits as akalogheri. They are viewed as unfortunate. They just disappear.
Even when one dies at ripe old age, after leading an exemplary life, if he is not accorded a befitting burial, he is not worthy of admittance into the comity of ancestors. This requirement has made traditional Igbo burials very expensive. The higher the social standing of the dead, the more expensive the burial. The more the titles and membership of prestigious community institutions the dead had, the more elaborate the rituals will be at death. If the dead person's progeny are not able to meet these requirements, the dead person will not qualify to enter the comity of the ancestors. Their spirit will not become an akalogheri but will hover around their family, causing bad omens among them until the dead person is given a befitting burial and committed to the comity of ancestors.

Children are very important in the Igbo concept of meaning. A member of the community who dies unwed is regarded as a total loss to the community, especially if they died at ripe old age. Even if such a person sired children, it does not free him from such societal approbations as among Ndigbo, a man is not deemed the father of a child if he did not pay any dowry on the mother's head. Such a person, at death does not qualify to enter the comity of the ancestors. However, he does not become an akalogheri. He simply disappears.

Reincarnation among Ndigbo. Ndigbo believe that their ancestors come back to their families in the form of newborns. However, Ndigbo do not believe that the newborn is the same person as the ancestor. They recognize the newborn as a brand new person with a unique identity. However, because the newborn is a reincarnation of an ancestor, the newborn is viewed to be under the influence of the ancestor. As the child grows older, Ndigbo look out for the traces of the personality of the ancestor in question in the attitudes of the child. This phenomenon can be viewed like the seed. Although the planted seed is manifested in the new seed it yields, the new seed is not said to be that very seed that was planted. Yet, there are always attributes of the planted seed in the new seed. So is the concept of reincarnation among Ndigbo. An ancestor is said to have manifested in a newborn via reincarnation, however, as in the analogy of the seed, the newborn is not identical with the ancestor, though related.

In Igbo ontology, the ancestor does not leave the comity of ancestors at reincarnation. While reincarnating among the living, the ancestor continues to dwell in the comity of ancestors from where he intercedes for the family he has left among the living. He continues to perform the important task of watching out for his family against any spiritual harm. Reincarnation of an ancestor is not limited to only one newborn. An ancestor may reincarnate in more than one newborn even contemporaneously.

The dead who did not qualify to be committed to the comity of ancestors cannot reincarnate. Among the Igbos, only the dead who have been fully committed to the comity of ancestors have the power to reincarnate. Conversely, those who died at unripe age, those who did not lead ethical lives, those who died from taboo diseases, those who did not marry and those who were not accorded befitting burials, do not have the power to reincarnate.

Ethical Implications of Igbo Conception of Death. In all human societies, the meaning of death decisively influences the ethics of the society. The fate of man in death determines significantly, the ethics he would abide with prior to death. If death is not the final event of man, if there is another form of existence beyond death which requires some prior ethical choices, man's ethics while alive would definitely be influenced by such requirements. 
Ndigbo are no different. The meaning of death is a significant factor in Igbo ethical system.

The greatest ethical requirement among the traditional Igbo is harmony with the community. Failure to maintain harmony with the society will lead to the ultimate dissociation which is represented in the concept of akalogheri the ostracized spirit. The akalogheri neither joins the comity of ancestors nor the living since it is already dead. It continues to hover endlessly in desolation and loneliness.

In the lgbo ontology, morality is not directed to God or a god but the community. Although Ndigbo fear retributions from the gods as consequences of evil, such retributions are not feared in death but while alive for Ndigbo do not believe that there is either a god to reward good deeds at death or a demon to torment man for his evil deeds at death. Ndigbo have a thoroughly materialistic ontology. Morality is not seen among the Igbos to originate from God but in the community. The community is the ultimate judge of man's behaviors.

Again, prestige is of enormous value among Ndigbo. The more prestigious a man was while alive, the more influential an ancestor he would become at death. This perhaps contributes greatly to the penchant for title taking among Ndigbo.

God, Heaven and Hell in Igbo Concept of Death. God as a monotheistic entity responsible for the universe was unknown in lgbo ontology. However, the missionary generation overreached themselves in trying to invent such entity in Igbo ontology due to their erroneous perception that belief in a monotheistic God was a sign of religious advancement. Thus words like Chukwu and Chineke acquired new meanings. But Chukwu initially referred to the Arochukwu deity. Its meaning had to be changed by missionaries to chi ukwu - the great god. But that is misleading. The Aros did not know any monotheistic god when they named their town Arochukwu. The Chukwu Abiama from which Arochukwu was named was not conceived by the Aro as a universal God, contrary to the impression the missionary generation created. Chukwu Abiama was a localized god. It dwelt in a forest in Arochukwu known as Okonto. The Aro did not see it as the creator of the universe, but as an all knowing spirit-force that had the capacity to know the truth of all events. Hence, its oracle, Ibin Ukpabi was a reliable arbiter of disputes. If Ndigbo knew Chukwu as a universal God, it would have been worshiped in every Igbo community. However, Chukwu was only associated with the Aro and their diaspora communities.

Likewise, Chineke was rendered as Chi na-eke - the God who creates. That is equally misleading. Chi meant the personal god while Eke meant the principle of creation. Chi did not mean gods in general. Ndigbo did not refer to the individual gods they worshipped as chi. For instances, Amadioha, Ahiajoku, Orashi, Ogwugwu, Idemili, Ala etc. which were gods worshiped by Ndigbo were never addressed with the word "chi". Chineke, translates as the "God that creates", therefore, is a missionary creation. It was not previously known among Ndigbo. If Ndigbo knew about Chukwu or Chineke before the arrival of the missionaries, they would have worshipped them. They would have built shrines to honor them. There would have been feast days dedicated to them, and they would have been severally mentioned in Igbo folklores. But that is not the case. Chukwu remained an Arochukwu deity. Appropriately, it had only one shrine at Arochukwu. It was worshipped only by the Aro. Other Igbo merely consulted it. Chineke did not exist at all. It is a portmanteau of chi and eke. These were different principles in the lgbo pantheon.

So, God was unknown to Ndigbo. Likewise, the heaven in which he dwelled. In Igbo ontology, there is no room for man meeting god, either in a vision while alive or in heaven after death. Traditions that recognized a supreme God always had folklores of individuals' visions of God. Ndigbo had none. Ndigbo did not consult God in times of perplexities, they consulted the oracle instead. While alive, the Igbo aspired to join the comity of ancestors. Neither God nor heaven was in the picture. The same is also applicable to hell. The punishment for immorality after death was the refusal of admittance into the comity of ancestors.

Clearly, the concept of death among Ndigbo did not factor in God, heaven or hell. That was the case for the very reason that these concepts were unknown to Ndigbo (Ezeh, 2012). They neither shaped ethical behavior among Ndigbo nor did they contribute to the meaning of life or death among Ndigbo.

The Igbo Concept of Death in Relation to Mainstream Concepts of Death

Although the Igbo concept of death is intrinsically materialistic, it is not atheistic. Although Ndigbo were neither hoping for a heaven nor scared of a hellfire, they looked forward to a meaningful survival of death based on the fulfillment of certain ethical conditions. This is unlike materialistic atheism that believes that personality and consciousness disappear at death decomposing into matter of which they were composed without any spiritual or afterlife residue. Ndigbo however, believe that death is a continuum of life. The community has an invisible, spiritual part which is peopled by the ancestors. The focus of the ancestors however, is neither themselves nor a god but the community.

The Christian concept of death bears significant similarities to the Igbo concept of death. There is a mutual belief in an afterlife. There is a mutual belief that morality determines one's fate in the afterlife. There is a mutual belief that the dead intercede for the living. But while the Christian concept of death is otherworldly, the lgbo concept of death is earth bound. In the Christian ontology, God is the focus of the afterlife. Among Ndigbo, the community is the focus of the afterlife. The Christian heaven exists in a distant realm entirely different from the earth. Among the Igbos, the ancestor well in a spiritual part of the community.

The objects of the Christian afterlife are splendor, joy and the contemplation of God. The objects of the Igbo afterlife are prestige and harmony with the community. In the Christian ontology, God passes the judgment on the fate of the dead. In the lgbo ontology, the community passes the judgment. There is no formal judgment though but in its consciousness, the community consigns its dead to where they belong. The Christian ontology makes provision for hellfire, where an anti-God, the devil reigns and serves punishment with those who had failed to follow the will of God. There is no such phenomenon in the lgbo ontology. Even the akalogheri that is barred from entering the comity of ancestors is not subjected to any community of sufferers subject to any god or anti-god. The akalogheri suffers no physical pain but the restlessness and desolate loneliness that comes from being barred from the community of the living and the comity of ancestors.

While the Christians believe that life in the afterlife, for good or for bad is eternal. Ndigbo reserve eternity only for the ancestors and the akalogheri. Those who die young, who didn't marry or who had died from a taboo disease 
simply disappear. There is no eternity for them in the afterlife.

\section{Critique of the Igbo Concept of Death}

Ndigbo, like the rest of the world have refused to accept the biological finality of death. Like the rest of the world, Ndigbo have sought to dilute the disruptive effects of death in the human society by consciously positing an ontology in which the human personality defies the finality of death and continues to maintain existence even after death. All this is predicated on a supposed extra-biological nature of consciousness which is deemed to function somehow independently of matter. The entire gamut of the meaning of death in Igbo ontology is predicated on this assumed more-than physical nature of consciousness.

Ndigbo neither believe in resurrection nor rapture. However they believe that consciousness and personality live on in the comity of the ancestors. If consciousness is proven to be a thoroughly material phenomenon that returns to earth with the rest of the body, the whole gamut of meanings associated with death in lgbo ontology would be null and void as they would be fallacious and nonfactual. Ndigbo do not point to any evidence as the justification for the claimed survival of consciousness beyond death. Even the immortality of personality among the Ndigbo is not universal. Dead infants just disappear. Ndigbo have no accounts of what happens to their personalities. Even youths who die just disappear. They don't enjoy personality immortality in Igbo ontology. What happens to them then? Is the nature of their consciousness different from that of the elders? Apparently, Igbos believe in selective personality immortality. From all indications, only two sets of people enjoy personality immortality in Igbo ontology: the elderly good and the truly evil. The elderly good, who of course must have married and had children, achieve personality immortality at death. They join the prestigious comity of ancestors who intercede for their families and the community. The truly evil on the other hand, become akalogheri wandering spirits who can neither disappear nor be integrated into the comity of ancestors. They become nuisances at the periphery of the community. Ndigbo however, have no form of immortally for those who fall outside above categories above: the youthful good, infants and the unmarried. The Igbo worldview is silent on the fate of their personalities after death.

Ndigbo have the phenomenon of ogbanje - the recurring infant. The infant which dies and is literally conceived and born again. Although, the phenomenon clearly demonstrates immortality of a sort, Ndigbo, however do not ascribe them personality let alone immortality. The ogbanje phenomenon was eventually proved by science to be a fallout of the SS genotype. Genotypes were unknown in traditional Igbo societies. The children with sickle cell anemia rarely survived. As the parents who were obviously a genotype mismatch continued to give birth to sickle cell anemic infants who continued to die, the infants were classified as ogbanje. Ndigbo are silent on the whereabouts of the personalities of these infants between death and rebirth (not reincarnation) simply because, Ndigbo, like most African societies do not ascribe personality to the infant.

The doctrine of reincarnation of the dead in lgbo ontology is fraught with many peculiarities. At reincarnation, the ancestor retains his personality in the comity of ancestors. But he is also said to have reincarnated in the infant in the community. How could a personality be existent in the comity of ancestors and an infant at the same time?
More puzzling is the belief that same ancestor could be reincarnated in multiple infants in the community. Has the ancestor achieved a duplication of personality?

What Ndigbo really mean by reincarnation could be reducible to "influence". When Ndigbo say that an ancestor has been reincarnated in an infant, they do not mean that the ancestor has started a new life in a new body. Ndigbo clearly recognize the distinct identity of the infant. But however believe that the infant is under the influence of the personality of the ancestor in question. Although, sometimes the parents may affectionately address the infant as if it were the actual ancestor, it doesn't go beyond that for the same parents may equally make sacrifices and pour libations to the same ancestor and not the infant! It is of significant import to note also that Ndigbo do not refer to adults as reincarnations of anyone.

Also, in the lgbo ontology, everybody is a reincarnation of somebody. Even the ancestor was a reincarnation of somebody else. So, whose personality actually reincarnates if reincarnation were really literal? It is clear that "reincarnation" as used in Igbo ontology is directly reducible without residue to "influence". The contrary would be a logical absurdity.

From the foregoing, it is clear that Ndigbo like the rest of humanity merely grappled with the crushing finality of death by putting forth not so consistent explanations, beliefs and practices to ameliorate the brutal facticity of the finality of death. Like the rest of the world, Ndigbo sought to give meaning to their existence by giving meaning to death. The gaps in the meaning of death in Igbo ontology, represent the limits of human knowledge. There is really no "outside" to the cosmos known to man. The meaning of death is paradoxically but directly tied to the meaning of the cosmos. To explain death, the meaning of the cosmos has to be comprehensively explained. If the cosmos were a mere meaningless happenstance, death then would truly be the final event in man. Ndigbo, ipso facto would be wrong about the meaning of death. But if the cosmos has evidence of order and plan, it would be impossible to dismiss the epistemological value of the meaning of death in Igbo ontology. But man can never comprehensively decode the cosmos because he has no access to an "outside" of the cosmos. Like Archimedes, man has no access to a fulcrum upon which to stand and view the cosmos independently.

\section{Conclusion}

This work set out to portray what death meant in Igbo ontology. Like the rest of the world, Ndigbo philosophically confronted death and came up with a plausible explanation of death. The explanation was basically materialistic as Ndigbo were never an otherworldly people. The ontological focus of Ndigbo was the community. Both death and life took place in, and for the community. Man existed in, and for the community. The self had meaning only in the community - I exist because we are. Ndigbo see death as disruptive when it is abrupt. But death at mature old age in a life well lived is celebrated among Ndigbo. When it is so, death subject to a befitting burial becomes an invitation into the prestigious comity of the ancestors. Only the ancestors can reincarnate. It is an honor not open to all the dead.

Death could also mean the ultimate anguish, for the akalogheri the evil doer. It could be a rejection from the comity of the living and the dead - the community; the greatest anguish the Igbo the self could suffer. Death could also be a disappearance into oblivion, as happened to 
youths and infants. They have no immortality of any sort. They died unripe, therefore, could not be admitted into the prestigious comity of the ancestors. In death as in life, it is the ultimate desire of the lgbo to be with the community. Hence, the Igbo dead are buried in their homesteads, and not at the cemetery. It is the rationale for going through enormous expenses to fly the dead Igbo from Asia, Europe or America to their homestead in their village in the lgbo African community for a befitting burial and proper commitment to the comity of ancestors. If this were not done for them, they were considered lost to the Igbo African community and would never traditionally be counted as dead even in a thousand years to come. The Igbo live for the community. In death, he dies for the community, and as an ancestor, he exists still for the community, even in death.

\section{REFERENCES}

Achebe, Chinua (1986). Things Fall Apart. London: Heinemann. (In English).

Ameh, G. (2017, August 7). What new DNA test result reveals about Igbos, Jews. Daily Post. Retrieved from http://dailypost.ng/ 2017/08/07/new-dna-test-result-reveals-igbos-jews/ (In English).

Anuolam, C. (1993). Igbo Value and Care for Life. Pamplona. Retrieved from https://core.ac.uk/download/pdf/83562852.pdf (In English).

Anyanwu, C. (1988). The meaning of ultimate reality in Igbo cultural experience. in Ultimate Reality and Meaning. Pp. 84-101. (In English).

Chukwuelobe, Matthew (1995). Language and Igbo philosophy: Towards an Igbo Phenomenology of language. Philosophy Today. Vol. 39, Issue 1, Spring. Pp. 25-30. DOI: 10.5840/philtoday199539128. (In English).

Egudu, R. (1992). African Poetry of the Living Dead: Igbo Masquerade Poetry. Edwin Mellen Press (In English).

Ezeh, P. (2012). The Ekwensu semantics and the Igbo Christian theolinguistics. International Journal of Research in Arts and Social Sciences, 4: 501-508. Retrieved from https:// academicexcellencesociety.com/book_critique.pdf (In English).

Forest, T. (1994). The Advance of African Capital: The Growth of Nigerian Private Enterprise. Edinburgh University Press for the International African Institute (In English).

Ikechukwu, N. (2017). The living-dead (ancestors) among the Igbo-African people: An interpretation of Catholic sainthood. International Journal of Sociology and Anthropology, 9(4). pp. 35-42. DOI: https://doi.org/10.5897/IJSA2017.0719 (In English).

Ikwuemesi, Chuu Krydz \& Onwuegbuna, Ikenna Emmanuel (2018). Creativity in calamity: Igbo funeral as interface of visuality and performance. Continuum. 32:2, 184-200. DOI: https://doi.org/ 10.1080/10304312.2017.1391176 (In English).

Isichei, Elizabeth (2002). Voices of the Poor in Africa. (Rochester Studies in African History and the Diaspora.) Rochester, N.Y.: University of Rochester Press. P.81 (In English).

Kalu, P. (2017, August 3). Anioma: We are Igbos of western Nigeria. eTimes. Retrieved from https://etimes.com.ng/aniomaigbos-western-nigeria/ (In English).

Leonard, A. (1968). The Lower Niger and its Tribes. London: Frank Cass. (In English)

Lovejoy, P. (2003). Trans-Atlantic Dimensions of Ethnicity in the African Diaspora. Continuum International Publishing Group. pp. 92-93. (In English).

Miller, F. G. (October 2009). Death and organ donation: back to the future. Journal of Medical Ethics. 35 (10): 616-620. DOI: 10.1136/jme.2009.030627 (In English).

Mwakikagile, G. (2006). African Countries: An Introduction with Maps. Continental Press. (In English).
Myers, F. (1903). Human Personality and its Survival of Bodily Death. New York: Longman, 416 p. (In English).

Nwoga, D. (1984). Nka na Nzere: The Focus of lgbo World. Ahiajoku Lecture, Owerri: Culture Division, Ministry of Information, Culture, Youth and Sports. (In English).

Ogbonna, O. (2009). Individual Freedom in African Communalism: An Inquiry. Retrieved from http://www.unn.edu.ng/ publications/files/images/OGBONNA,\%200BIORA\%20B.pdf (In English).

Olaudah, E. (1837). The Interesting Narrative of the Life of Olaudah Equiano. Knapp. pp. 20-21 (In English).

Onochie, O. (2015, September 25). Are Igbo the lost black Jewish tribe? The Guardian. Retrieved from https://guardian.ng/ features/are-igbo-the-lost-black-jewish-tribe/ (In English).

Rucker, W. (2006). The River Flows on: Black Resistance, Culture, and Identity Formation in Early America. LSU Press. (In English).

Trothen, T. \& Mercer, C. (Eds). (2017). Religion and Human Enhancement: Death, Values, and Morality. London: Palgrave Macmillan. DOI: https://doi.org/10.1007/978-3-319-62488-4.

Veeranah, R., Cornell, B., Pour, N., et al. (2010). Little genetic differentiation as assessed by uniparental markers in the presence of substantial language variation in peoples of the Cross River region of Nigeria. BMC Evolutionary Biology. DOI: https://doi.org/ 10.1186/1471-2148-10-92.

Zahan, D. (1877). The Religion, Spirituality, and Thought of Tradition. Chicago.

\section{LIST OF REFERENCE LINKS}

Achebe Chinua. Things Fall Apart. London: Heinemann, 1986. Ameh G. What new DNA test result reveals about lgbos, Jews. Daily Post. 2017, August 7. URL: http://dailypost.ng/2017/08/07/ new-dna-test-result-reveals-igbos-jews/.

Anuolam C. Igbo Value and Care for Life. Pamplona, 1993. URL: https://core.ac.uk/download/pdf/83562852.pdf.

Anyanwu C. The meaning of ultimate reality in Igbo cultural experience. Ultimate Reality and Meaning. 1988. Pp. 84-101.

Chukwuelobe Matthew. Language and Igbo philosophy: Towards an Igbo Phenomenology of language. Philosophy Today. 1995. Vol. 39, Issue 1, Spring. Pp. 25-30. DOI: 10.5840/ philtoday199539128.

Egudu R. African Poetry of the Living Dead: Igbo Masquerade Poetry. Edwin Mellen Press, 1992.

Ezeh P. The Ekwensu semantics and the Igbo Christian theolinguistics. International Journal of Research in Arts and Social Sciences. 2012. 4: 501-508. URL: https://academicexcellencesociety.com/book_critique.pdf.

Forest T. The Advance of African Capital: The Growth of Nigerian Private Enterprise. Edinburgh University Press for the International African Institute, 1994.

Ikechukwu N. The living-dead (ancestors) among the IgboAfrican people: An interpretation of Catholic sainthood. International Journal of Sociology and Anthropology. 2017. 9(4). pp. 35-42. DOI: https://doi.org/10.5897/IJSA2017.0719.

Ikwuemesi Chuu Krydz \& Onwuegbuna Ikenna Emmanuel. Creativity in calamity: Igbo funeral as interface of visuality and performance. Continuum. 2018. 32:2, 184-200. DOI: https://doi.org/ 10.1080/10304312.2017.1391176.

Isichei Elizabeth. Voices of the Poor in Africa. (Rochester Studies in African History and the Diaspora.) Rochester, N.Y.: University of Rochester Press, 2002. P. 81.

Kalu P. Anioma: We are Igbos of western Nigeria. eTimes. 2017, August 3. URL: https://etimes.com.ng/anioma-igboswestern-nigeria/.

Leonard A. The Lower Niger and its Tribes. London: Frank Cass, 1968. 
Lovejoy P. Trans-Atlantic Dimensions of Ethnicity in the African Diaspora. Continuum International Publishing Group, 2003. pp. 9293.

Miller F. G. Death and organ donation: back to the future. Journal of Medical Ethics. October 2009. 35 (10): 616-620. DOI: 10.1136/jme.2009.030627.

Mwakikagile G. African Countries: An Introduction with Maps. Continental Press, 2006.

Myers F. Human Personality and its Survival of Bodily Death. New York: Longman, 1903. 416 p.

Nwoga D. Nka na Nzere: The Focus of Igbo World. Ahiajoku Lecture, Owerri: Culture Division, Ministry of Information, Culture, Youth and Sports, 1984.

Ogbonna O. Individual Freedom in African Communalism: An Inquiry. 2009. URL: http://www.unn.edu.ng/publications/files/ images/OGBONNA, \%20OBIORA\%20B.pdf.
Olaudah E. The Interesting Narrative of the Life of Olaudah Equiano. Knapp, 1837. pp. 20-21.

Onochie O. Are Igbo the lost black Jewish tribe? The Guardian. 2015, September 25. URL: https://guardian.ng/features/are-igbothe-lost-black-jewish-tribe/.

Rucker W. The River Flows on: Black Resistance, Culture, and Identity Formation in Early America. LSU Press, 2006.

Religion and Human Enhancement: Death, Values, and Morality / Trothen T. \& Mercer C. (Eds). London: Palgrave Macmillan, 2017. DOI: https://doi.org/10.1007/978-3-319-62488-4.

Veeranah R., Cornell B., Pour N. et al. Little genetic differentiation as assessed by uniparental markers in the presence of substantial language variation in peoples of the Cross River region of Nigeria. BMC Evolutionary Biology, 2010. DOI: https://doi.org/ 10.1186/1471-2148-10-92.

Zahan D. The Religion, Spirituality, and Thought of Tradition. Chicago, 1877.

\section{Ебо Сократ,}

Інститут фундаментальних досліджень, Федеральний університет (Отуоке, Баєлса, Нігерія) e-mail: eboss@fuotuoke.edu.ng.ebosocrates@gmail.com,ORCID http://orcid.org/0000-0003-4062-8487

\section{СМЕРТЬ В ОНТОЛОГІЇАФРИКАНСЬКОГО НАРОДУІГБО}

Смерть - це виклик будь-яким дослідженням людини, їі кінцева головоломка. Смерть незмінно знаходиться в центрі людських пошуків сенсу свого існування. Різні культури в різні епохи наближалися до смерті через широку гаму значень і смислів. Африканська спільнота Ігбо, як і інші культури у світі, зіткнулася зі смертю у своїй спробі філософського обґрунтування сенсу свого життєвого досвіду. Людина не повинна просто зникати. Ігбо, як і більшість представників людського роду, відмовляються остаточно прийняти смерть. Серед Ігбо смерть - це континуум. Померлі продовжують жити в пам'яті й діяльності спільноти. Їхній статус на землі мертвих, яка, до речі, не є далекою від місця проживання спільноти, залежить від того, наскільки добре вони жили й наскільки добре їхні нащадки виконували свої обов'язки по відношенню до них, особливо щодо їх поховання. В онтології Ігбо суспільство є центром існування. Навіть у світі мертвих мертві існують для своєї громади. Вони повинні продовжувати робити добро для спільноти, забезпечувати сприятливі умови для богів. Навіть коли мертві не викликають прихильності предків, вони не просто зникають. Вони витають навколо громади, спричиняючи великі незручності для їх близьких, сімей та спільноти в цілому. Коли Ігбо помирає, він не бажає ані бути об'єднаним з богом на небесах, ані бути покараним демоном у пеклі. Його істота по суті визначається як продовження "перебування з громадою". У статті цей унікальний досвід Ігбо щодо розуміння смерті фіксується за допомогою вивчення письмових джерел, усних традицій та інтерв'ю, безпосереднього спостереження за звичаями спільноти на практиці та аналізу живого спілкування. Серед існуючих у світовій філософрській спадщині інтерпретацій смерті необхідно чітко виокремлювати унікальну концепцію Ігбо, яка одночасно стосується й проблеми сенсу життя.

Ключові слова: смерть; пошуки сенсу свого існування; афрриканське суспільство ігбо; концептуалізація смерті в уявленнях ігбо.

\section{(c) Ebo Socrates}

Надійшла до редакції: 17.05.2019

Прийнята до друку: 07.06.2019 